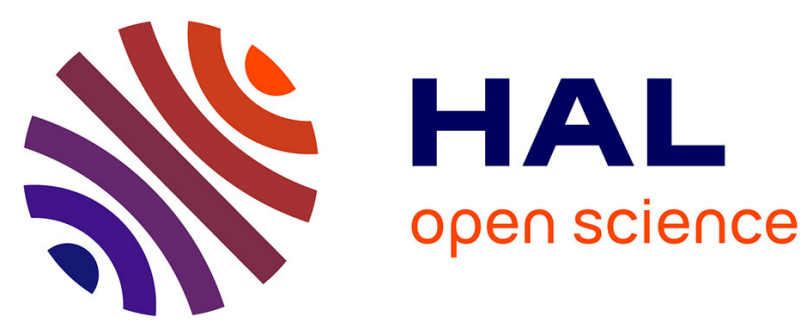

\title{
International exchanges and double diplomas with several partners: experience feedbacks in Grenoble with a bachelor in wireless networks and security
} Jean-Marc Thiriet, Denis Lubineau, Hamed Yahoui

\section{- To cite this version:}

Jean-Marc Thiriet, Denis Lubineau, Hamed Yahoui. International exchanges and double diplomas with several partners: experience feedbacks in Grenoble with a bachelor in wireless networks and security. EAEEIE 2013 - 24th EAEEIE Annual Conference on Innovation in Education for Electrical and Information Engineering, May 2013, Chania, Greece. pp.55-59. hal-00829826

\section{HAL Id: hal-00829826 \\ https://hal.science/hal-00829826}

Submitted on 3 Jun 2013

HAL is a multi-disciplinary open access archive for the deposit and dissemination of scientific research documents, whether they are published or not. The documents may come from teaching and research institutions in France or abroad, or from public or private research centers.
L'archive ouverte pluridisciplinaire HAL, est destinée au dépôt et à la diffusion de documents scientifiques de niveau recherche, publiés ou non, émanant des établissements d'enseignement et de recherche français ou étrangers, des laboratoires publics ou privés. 


\title{
International exchanges and double diplomas with several partners: experience feedbacks in Grenoble with a bachelor in wireless networks and security
}

\author{
Jean-Marc Thiriet ${ }^{1,2}$, Denis Lubineau ${ }^{2}$, Hamed, Yahoui ${ }^{3}$ \\ ${ }^{1}$ Univ. Grenoble Alpes, GIPSA-lab, F-38420 Grenoble \\ CNRS, GIPSA-lab, F-38420 Grenoble \\ jean-marc.thiriet@ujf-grenoble.fr \\ ${ }^{2}$ Univ. Grenoble Alpes, IUT 1, F-38 402 Grenoble \\ jean-marc.thiriet@ujf-grenoble.fr, denis.lubineau@ujf-grenoble.fr \\ ${ }^{3}$ Université Claude Bernard Lyon 1, Laboratoire Ampère, Lyon \\ hamed.yahoui@univ-lyon1.fr
}

\begin{abstract}
An “internationalized" bachelor (actually last year of a bachelor course) has been launched in September 2007 in Grenoble. From this time, around 15 students from all around the world spent each year a complete academic year in Grenoble, in a multicultural environment, in order to pass a French "licence professionnelle" (Professional Bachelor) taught in English in the field of wireless networks and security. Under some circonstances, some of the students get the possibility to obtain the French diploma.

The adaptation of the curriculum content, the multicultural environment for the academic project as well as for social activities, and the international recruitment process are important aspects to deal with, and will be explained in the paper.
\end{abstract}

Keywords - Electrical and Information engineering multicultural aspects - double diploma - international programme - networking and telecommunications - Exchanges of students

\section{INTRODUCTION}

Taking account of the experience in the international thematic networks activities (THEIERE [1], EIE-Surveyor [2], ELLEIEC [3]), Univ. Grenoble Alpes has taken the opportunity to launch in September 2007 an international programme at the Bachelor level in Networking and Telecommunications [4]. This international programme is built around a classical accredited programme called "Licence Professionnelle en Réseaux Sans Fil et Sécurité".

This international programme has been built around an international consortium, and has been used as a feasibility benchmark during the ELLEIEC thematic network [3]. Something which has been implemented, thanks to this experiment, is the possibility for the students received in exchange programmes (for instance ERASMUS students in Europe) to get the French "licence professionnelle", together with the diploma prepared in the home institution. This is actually a strong added value to the ERASMUS experience, acting also as a guarantor of good teaching quality and student involvement, since the fact to validate the French diploma together with the home institution one, implies generally that the student works really seriously.....
The second section presents the programme, then some aspects of the multidimensional dimension are explained. The fourth section explains the possibility to get the French diploma for some exchange students, explaining the rules. Section V gives more input about the categories of students. Section VI discusses the added value of mobility of teachers whereas section VII presents the communication strategy. Section VIII deals with discussions on difficulties and successes.

\section{Presentation of the Programme}

In the French system, a bachelor programme is a three-year programme (180 ECTS). We have "internationalised" (international recruitment, multicultural approach, courses given in English, teaching of FLE (Français Langue Etrangère)) the third year only. This programme was presented before [4]. We can remind that the programme is composed of generic courses (FLE, English, Project management, Internet law, Communication skills), basic technical and scientific courses (Networking, Telecommunications, Databases) and advanced scientific and technical courses (mobile communications, wireless networks, security of networks). The programme is also composed of an academic project (explained also in the section dedicated to multicultural aspects) as well as an internship either in a company or in a research lab.

\section{INTERNATIONAL AND MULTICULTURAL DIMENSIONS}

The students come from various countries and continents (see also section V).

The list of languages below shows how many mother tongues were the ones used by our international students, during this six-year period (you can try to guess which are these languages, and there is one intruder...):

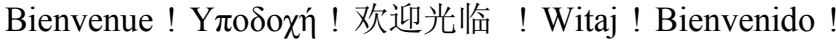
Bem-vindos! Ekkaabo! Karibu ! Tervetuloa ! Vitaj ! товчхон ! Dobrodošli! Hoş geldiniz ! ! وسهـلا اهلا Bonvenon !

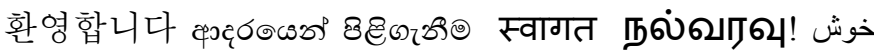
! Woezo ! Welkom! 
The first aspect is that English is the common language. French students attending the international class knows that they should interact with everybody, including other French students and teachers, in English. For non-French speaking students, it is encouraged to develop skills and capacities in French, and in this case interactions in French are encouraged, despite they're generally not really usable before January (which means at the end of the fall semester).

A second aspect of the internationalisation is to balance home institutions of students (generally not more than two coming from the same institution and not more than three from the same country). International students come to France also to have interaction with Frenchmen, and Frenchmen may have an interest also in participating in an international English-taught programme in order to get an accredited wellknown and recognised French diploma. It is one of the reason why we consider to recruit 3 to 4 French students in the international class each year.

A third aspect is the induction week. During the first week of class, we propose specific activities like "administrative aspects", preparation for each student of a presentation of her/his country, academic system, etc... At the end of the week, there are formal presentations of the students about their country. It is interesting because we can check the communication and linguistic capabilities, it is also a time where students are together, "induced" in order to be part of an actual group, and not a poor international student lost somewhere in France alone.

A fourth important aspect is the academic project. The academic project consists in the design, installation and validation of a secured-networked architecture. It is mainly a technical project. But the students work as a team of 6 students split into 3 sub-teams of 2 . One of the rule is that each sub-team is intercontinental, so the team is completely international. The students have to manage their project, in the international environment which is the reality of the group, this is sometime an excellent and not easy exercise for students.

\section{IV.POSSIBILITY TO GET THE FRENCH DIPLOMA FOR EXCHANGE STUDENTS}

Results (diploma)

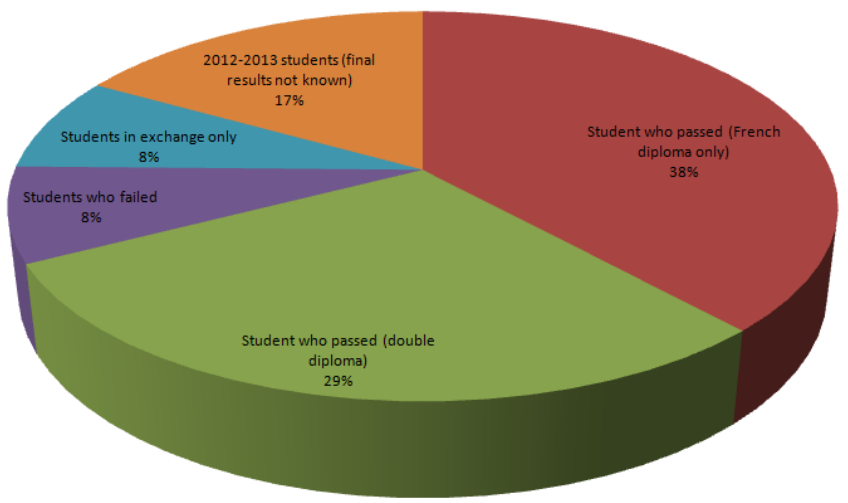

Fig. 1 Diploma obtained by students, $29 \%$ obtained a double diploma
In order to give an added value to the international exchange experience, we have decided to give international students the possibility to pass the French diploma. The rule is quite simple: students come with at least a two-year of a bachelor programme passed in networking and telecommunications or a relative field, in this case they are in the same situation as classical French students, so if they succeed in our international programme, they get the French diploma. From 2007-08 until now, international students coming from Liège (BE), Krakow \& Gliwice (PL), Prague \& Ostrava (CZ), Kosice (SK), Vigo and Valencia (ES), Helsinki (FI), Crete (GR), Groningen (NL) passed as ERASMUS students the French diploma at the same time as diplomas in their home institution (sometimes students need an extra semester in their home institution depending on the percentage of recognition of the French classes in the home institution curriculum). Brasilian students from CEFET Minas Gerais also obtained the French diploma, within the frame of a memorandum of understanding for exchanges of students. We are at the moment working on a memorandum of understanding with a Malaysian institution, to enlarge our set of partners.

Fig. 1 shows the figures about students. 89 students are considered in this figure (all the registered students from the beginning (see section $\mathrm{V}$ for other figures on recruitment)).

$17 \%$ are the 2012-2013 students so we should wait to see if all of them or only some will pass the diploma, but we know that among these 15 students, 7 are registered for a doublediploma ( $8 \%$ of the global set), $8 \%$ were exchange students only (specific programme, no French diploma), $8 \%$ failed and $29 \%$ got a double diploma and $38 \%$ only the French diploma (it is generally the case for French students and international students outside exchange programmes, it means that they just register as classical students).

\section{CATEGORIEs OF STUdENTS, RECRUITMENT}

For 2013-2014, eighty applications have been received, among which 15 French, 10 students in exchanges (ERASMUS, Brasil) which means students who have been selected and agreed by partner institutions, and 55 from everywhere in the world. Among these 55 records, some are not eligible. At the end, we hope to have a balanced group with 8 or 9 exchange students, 2 or 3 French students, and 3 to 5 international students outside exchange programmes, for the incoming 2013-2014 academic year.

For recruitment, it is requested that applicants provide their certified results, a certificate level in English (TOEFL 520 (paper-based exam) or 210 (computer-based exam), TOEIC 700, IELTS 5.5, BULATS 70), a CV and a covering letter showing their willingness to work in this international context.

Figure 2 shows the evolution of the size of the international group as a function of the time. Our target is 15 per year. 89 students, including the present students, have participated in our international programme. Results about diplomas obtained are given in section IV. 


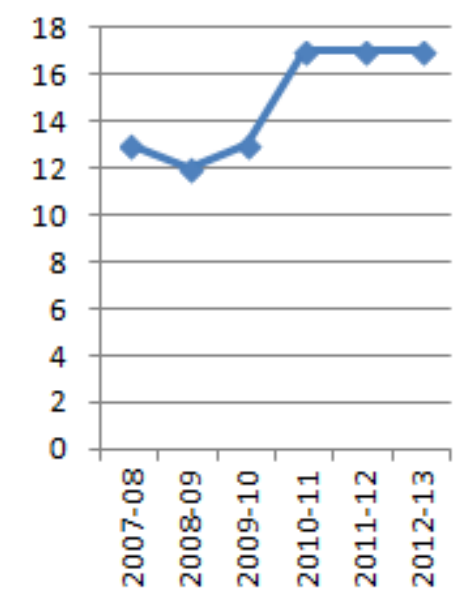

Fig. 2 Number of students from the origin

\section{European countries, without France, 31 students}

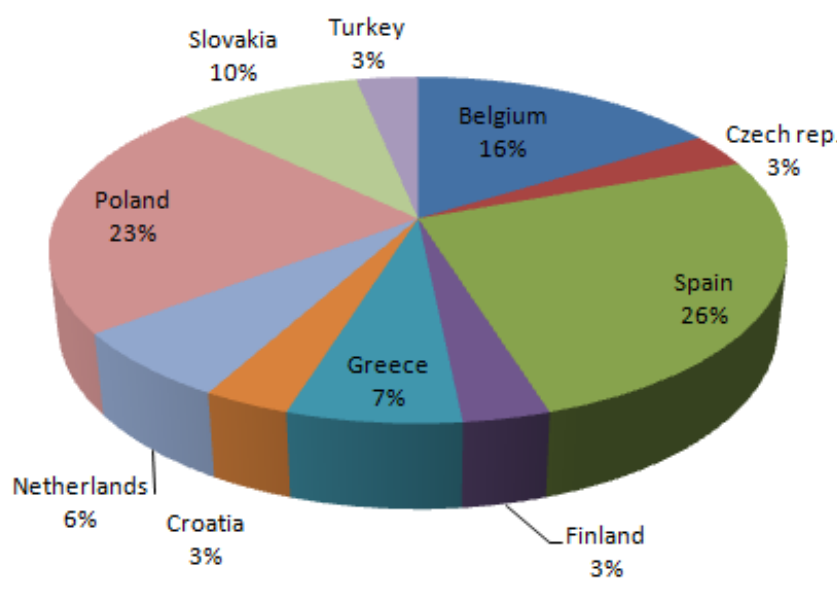

Fig. 3 Distribution of European students (without France)

Figure 3 displays the distribution of students among European countries. 31 students are coming from European countries. European students come generally within ERASMUS and passed a double diploma (except 5 who came in direct registration).

23 students came from France. The rule for them is to go abroad for the internship in a company or in a research lab at the end of the academic year. Among those 23, 18 went abroad (mainly Europe but also USA) for their internship.

Figure 4 displays the distribution of students among continents.

For Africa, students come from various countries (Ghana, Libya, Morocco, Nigeria, Tanzania). These students are coming from outside French-speaking Africa (except two from Morocco) and all these students come outside any exchange programme.

For Asia, students come from China, India, Iran, Mongolia, South Korea, Sri Lanka and there are this year also candidates from Bangladesh, Pakistan, Syria, Viet-Nam. All these students come from outside any exchange programme also.

\section{Per continent: $\mathbf{8 9}$ students}

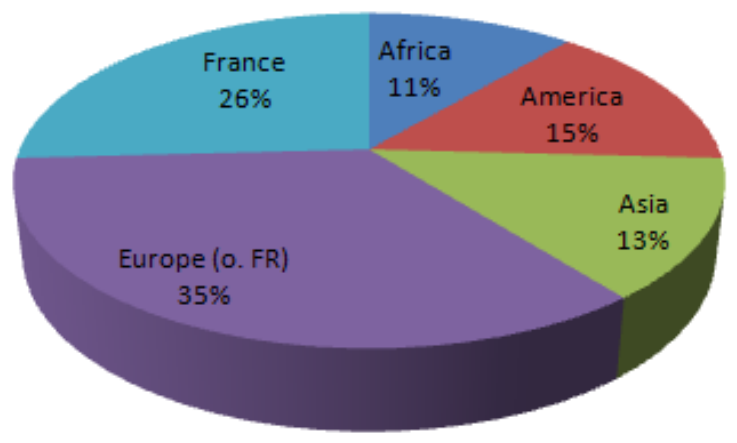

Fig. 4 Distribution of students per continents

For America, the situation is different because we have a specific exchange programme with one institution in Brasil and for USA, we take benefit of an ATLANTIS DESIRE2 exchange programme between Europe and USA [5]. Until now, 7 students came from Brasil in Grenoble in our programme, 6 US students came and attended at least partially our international programme (they had an "à la carte" programme) and 2 French students of our international programme went to the USA.

\section{TEACHER MOBILITY}

One interesting aspect of this program is to provide students with an international dimension, (see section III). One way to meet this goal is to invite European colleagues within "Staff-Erasmus" agreements to come to teach to our students. The purpose of this mobility teaching is twofold:

- open students to a European and multi-cultural perspective,

- allow exchanges between teachers: foreign visitors and local teaching staff.

In 2012-2013, the exchanges that have been made are the following:

- University of Brno, Czech Rep., and High School Province of Liège, Belgium with colleagues who came to teach about networks and security.

- Faculty of Law, Aristotle University, Greece with a colleague who came to teach about "Internet law" bringing a European and international dimension to this aspect which can be different in various countries. This is naturally fundamental to our students, with networks being interconnected in an international context.

- The Metropolia University, Finland, with a colleague who came for a course on "Communication in an international environment ". The Finnish colleague who came is a specialist in communication in an international environment, and the conference was particularly appreciated by students. 
It is not so international but interesting also: we use to have also people working in IT industry in Grenoble to come and give some conferences to the student. One of this colleague, working in a company, is an Englishman who talks about working in an international dimension from a company perspective.

\section{COMMUNICATION STRATEGIES}

To communicate about the program, it is important to have a strategy. The communication strategy consists of three aspects:

- A targeted communication towards an important network of partners, European partners from various projects and exchange programmes $[1,2,3,6]$ as well as extra-European partners, this network is important and ensures us with between 4 and 8 students per year.

- An information on the website of our university is also very important. Non-European students in particular look for the rankings of universities, and then they look on the websites of the ranked universities for existing curricula in their disciplines. Thus some come in Grenoble using this strategy.

- A communication at the national level via Campus France, which is an organization linked to the French Ministry of Foreign Affairs. It is possible to find there the list of programmes and curricula available in France for international students, in particular the English-taught programmes is also available.

\section{SUCCESSES AND DIFFICULTIES}

The implementation of an international programme is a collective adventure, in which three or four aspects should be present, as keys to success:

- An institutional commitment as a strong encouragement from the University. For our part, our institution was very keen to support us, helping us for example with the organization of a seminar with Scottish partners in order to be trained how to "teach in English in a multicultural environment". It was a good preparation for us. Another support comes from the fact than one hour of course given in English is accounted as 1.12 hours compared to the same course given in French.

- An educational team "ready to play", in our case, for all core courses except one, colleagues from our Department accepted to be part of the team and accepted to teach in English. For other courses, we invited colleagues from other Faculties to help us, and we found other colleagues.

- A "project manager" who is dynamic and enterprising. It is true that in these kinds of adventures we had to invent procedures for recruitment, take care of the multicultural environment, help for housing and administrative environment... and it is necessary to have some degree of innovation and motivation...

- An international network of partners to establish part of the recruitment, guarantee quality of the students we receive, and ensuring some stability in the recruitment.

\section{CONCLUSIONS}

After six years, we can say that this experience is an actual success. It allowed us to attract in Grenoble and France some students who would not have come without this programme. It is also a way for us to open our mind outside classical Frenchspeaking countries. Students attending this international programme are generally really motivated: some of them are attracted by the international dimension as an added value, some by the possibility to get a double diploma, some because they want to stay in France either/or to prepare a master or to find a job.

We have a continuous partnership with some institutions.

French students also see this international programme as a good opportunity to pass an accredited French diploma in an intermational multi-cultural English-speaking environment as an added value.

A number of difficulties should not be neglected, such as the willingness of the teaching team to teach in English, and the overall organization to ensure the sustainability of this kind of program requires a significant interest among the leaders of this programme.

\section{ACKNOWLEDGMENT}

The authors wish to thank the European Commission for the grant in the Life long Learning Programme, the Executive Agency for its help and all the partners of the project for their contribution.

- Project Number: SALEIE 527877-LLP-1-2012-1-UKERASMUS-ENW - Instrument type: ERASMUS NETWORK - Project Number: ELLEIEC 142814-LLP-1-2008-FRERASMUS-ENW - Instrument type: ERASMUS NETWORK as well as the grants obtained by various consortia for:

- « Intensive programme » DOSSEE, « Developing Open Source System Expertise in Europe ».

- DESIRE2 Dependable Systems International Research and Educational Experience, http://www.desire.agh.edu.pl (thanks also to the US Department of Education for this project).

ERASMUS exchange programmes.

\section{REFERENCES}

[1] (Under the co-ordination of J.M. THIRIET \& M.J. MARTINS), Monograph: Towards the harmonisation of Electrical and Information Engineering Education in Europe", Ed. EAEEIE, August 2003, 350 pages, (ISBN, book version: ISBN 972-97738-2-3, ISBN: CD-ROM version: ISBN 972-97738-3-1).

[2] J.M. Thiriet, A. E. Ward, M. J. Martins, D. Deniz, D. Pasquet, M. Hoffmann, H. Fremont, H. Yahoui, O. Bonnaud, M. Robert, J. Barsics, J.V. Benlloch-Dualde, Results and dissemination of the EIE-Surveyor thematic network, $20^{\text {th }}$ annual EAEEIE Conference, Valencia, España, 22-24 June 2009. Poster session T4.P Digital Object Identifier 10.1109/EAEEIE.2009.5335450.

[3] ELLEIEC Project (greenelleiec.eu), Lifelong learning in ELECTRICAL and INFORMATION ENGINEERING in Europe, 2008-2012 Based on the results of the EU-funded Thematic Network ELLEIEC Project Nr. 142814-LLP-1-2008-FR-ERASMUS-ENW ISBN 2-9516740-7-4.

[4] Jean-Marc THIRIET, Denis LUBINEAU, Philippe BENECH, Emil NOVAKOV, Anna DERIOZ, Jean-Michel TERRIEZ, A New International "Professional" Bachelor's Degree in Wireless Networks 
and Security, $19^{\text {th }}$ annual EAEEIE Conference, Tallinn, Estonia, 30 June - 2 July 2008, pp.88-93, 978-1-4244-2009-4.

[5] A.J. Kornecki, W.Grega, T.B. Hilburn, JM Thiriet, M. Sveda, O Rysavy and A. Pilat, Transatlantic Engineering Programs: An Experience in International Cooperation, 20 pages, InTech Web, 2009 , http://intechweb.org/, ISBN 978-953-307-012-4, pp.65-84 in "Engineering the computer science and IT".

[6] Jean-Marc Thiriet, Hamed Yahoui, Carlos Vaz de Carvalho, Michel Robert, Juan Carlos Burguillo, Joseph Barsics, Sven Knockaert, Roel
Van Steenberghe, Wojciech Grega, "Réseaux internationaux pour la validation de modules internationaux accessibles à distance : exemple en réseaux de communication", Actes du 7ème Colloque Technologies de l'Information et de la Communication pour l'Enseignement, Nancy, 6 - 8 décembre 2010.ISBN 2-9516740-5-8, 6 pages. 